\title{
Where are the vrais dévots and are they véritables gens de bien? Eloquent Slippage in the Tartuffe Controversy
}

\author{
Dr Julia Prest, University of St Andrews \\ Buchanan Building, Union Street, St Andrews, KY16 9PH, United Kingdom \\ Tel: +44 (0)1334 463646; fax: +44 (0)1334 463677 \\ jtp22@st-andrews.ac.uk
}

\begin{abstract}
The famous controversy provoked by Molière's Tartuffe (1664-69) is usually read in terms of vrais and faux dévots and thought to turn on the question of sincerity versus hypocrisy. Here the vrai-faux dichotomy is challenged and a third term introduced in the form of the véritable homme de bien of Molière's Preface to the published edition of the play. In the slippage between a vrai dévot and a véritable homme de bien (considered by most critics to be synonymous), I argue, lies a value-judgment and the suggestion of an alternative, more secular worldview that persisted even in the 1669 version of the play. The scandal of Tartuffe thus lies less with the threat of religious hypocrisy and more with the possibility that true morality could be found outside the Church.
\end{abstract}

Keywords: Molière, Tartuffe, vrai dévot, faux dévot, controversy, véritable homme de bien

Exactly where and who are the oft-mentioned vrais dévots in Molière's Tartuffe (and the controversy that the play provoked) and are they, as the majority of critics have assumed, the same as the véritables gens de bien to whom Molière refers in his preface to the published version of the play? These are the questions that I will attempt to address here. In the course of my discussion, two related, key notions that have dominated the discourse surrounding the Tartuffe controversy from the 1660s to the present day will be 
challenged: namely that it should be read in terms of vrais and faux dévots and that, therefore, the difference between the two is a matter of sincerity versus hypocrisy. In so doing, I shall also challenge the assumption whereby the 1669 version of Tartuffe must, unlike earlier versions of the play, have been deemed acceptable to the Church simply because the ban on public performances was finally lifted that year. Instead, I shall proceed on the basis that the final version of the play may yet have contained material that was threatening to the Church but that the political climate had shifted sufficiently between 1664 and 1669 for the play to be performed. While the young Louis XIV could certainly not afford to ignore the views of prominent ecclesiastics and dévots around him, as he achieved a firmer grip on power in the course of the 1660s, he elected on occasion to act more independently than has sometimes been assumed. Just as his adulterous affairs were a locus for tension between France's King and her Church in the 1660s, so also was his attitude towards Molière's play (Prest 2010). ${ }^{1}$

Molière himself fuelled what was soon to become the vrai--faux model when he wrote in his preface, 'j'ai mis tout l'art, et tous les soins qu'il m'a été possible pour bien distinguer le personnage de l'Hypocrite d'avec celui du vrai Dévot' (Molière 2010, II, 92). Other contemporary sources that are commonly cited in support of this approach include the official, anonymous account of the 1664 fête, Les Plaisirs de l'île enchantée, at which Tartuffe was given its courtly première; the 1667 ordonnance by the Archbishop

\footnotetext{
${ }^{1}$ Indeed, the link between dévot disapproval of Louis's sexual proclivities and the Tartuffe controversy is made explicit in the Brossette-Boileau correspondence in which we read: 'Il [Molière] ne laissoit pas de songer aux moiens de trouver le moien de pouvoir jouer sa pièce. Madame, première femme de Monsieur, avoit envie de voir resprésenter Le Tartuffe. Elle en parla au Roy avec empressement, et elle le fit dans un tems où Sa Majesté étoit irritée contre les dévots de la Cour. Car quelques prélats, surtout M. de Gondrin, Archevêque de Sens, s'étoient avisez de faire au Roy des remonstrances au sujet de ses amours (avec Mlle de Lavallière, Mme de Montespan). D’ailleurs le Roy haïssoit les Jansénistes, qu'il regardoit encore la plupart comme les objets de la comédie de Molière. Tout cela détermina Sa Majesté à permettre à Madame que Molière jouât sa pièce' (Laverdet 1858, 563-64).
} 
of Paris (re)condemning the play; and Bourdaloue's sermon on hypocrisy. I would like to revisit each of these sources briefly in order to begin to problematize the vrai-faux model and the question of sincerity that supposedly sits at its heart. My aim is to deepen and nuance our understanding of this famous but rather misunderstood controversy.

The official account of Louis XIV's fête surely ranks as the most balanced among contemporary views on Tartuffe, for it neither condemns the play nor overlooks its explosive potential:

Le Roi connut tant de conformité entre ceux qu'une véritable dévotion met dans le chemin du Ciel, et ceux qu'une vaine ostentation des bonnes œuvres n'empêche pas d'en commettre de mauvaises; que son extrême délicatesse pour les choses de la Religion, ne put souffrir cette ressemblance du vice avec la vertu, qui pouvaient être prise l'une pour l'autre. (Plaisirs 1664, 597)

At first sight, this appears to conform to the vrai--faux model according to which true and false devotion are dichotomized and yet resemble one another closely (and it is of course the close resemblance that requires the would-be clear distinction suggested by dichotomy). Critics typically seize upon the opposition of bonnes and mauvaises æuvres and of vice and vertu, their ressemblance and their potential for confusion. But the distinction being made is in fact rather more subtle: it is between the bonnes auvres resulting from une véritable dévotion and those motivated by a vaine ostentation that will either taint those good works or exist alongside bad ones (it is not entirely clear which). So while it is true that the importance of motivation is upheld here, it is not absolutely certain that the authors of ostentatious good works are calculating hypocrites with another agenda à la Tartuffe or simply misguided would-be vrais dévots à la Orgon. We are also reminded of the crucial fact that seemingly good works are not an infallible gauge of sincerity of heart.

In his more partisan account, the Archbishop of Paris, Hardouin Perefixe, claimed in 1667 that Molière's play (now called L'Imposteur) was, 'd'autant plus capable de nuire à la Religion, que sous prétexte de condamner l'hypocrisie, ou la fausse dévotion, elle donne lieu d'en accuser indifféremment tous ceux qui font profession de la plus solide 
piété' (Perefixe 2010,1168). Here there is no mention of a close resemblance between la plus solide piété and la fausse dévotion; rather the suggestion is that Molière's portrayal of hypocrisy might provide grounds ('donner lieu') for accusing true devotion as well. Nor does Perefixe even state explicitly that such grounds (or even the accusations themselves) would be false -- only that they would spring from a portrayal of false devotion. And what are we to make of the conjunction 'ou' (does it indicate an overlap or a separation?) or of 'faire profession', which hints at a performative but also business-like element to true piety that could incorporate both hypocrites and sincere believers.

For Bourdaloue, in his fascinating sermon Sur l'hypocrisie, the question of a close resemblance reappears. When true or false religion is mocked, both are almost always implicated:

Comme la fausse dévotion tient en beaucoup de choses de la vraie, comme la fausse et la vraie ont je ne sais combien d'actions qui leur sont communes; comme les dehors de l'une et de l'autre sont presque tout semblables, il est non-seulement aisé, mais d'une suite presque nécessaire, que la même raillerie qui attaque l'une intéresse 1'autre, et que les traits dont on peint celle-ci défigurent celle-là.

(Bourdaloue 1864, II, 235)

In many respects, this quotation does conform closely to the vrai--faux paradigm, stressing as it does the external similarities between the two. But once again, we are faced with the uncomfortable admission that a person's deeds (actions) do not necessarily make known his sincerity or otherwise. False devotion not only looks very like true devotion (Tartuffe in clerical or semi-clerical dress); it also behaves very like true devotion, which Tartuffe does only some of the time. As Bourdaloue observes in his sermon, Sur la vraie et la fausse piété, 'On entre dans les hôpitaux, on visite des prisons, on console des affligés, on soulage des malades, on assiste des pauvres; et tel peut-être qui fait voir sur cela plus d'assiduité et plus de zèle, est celui qui exerce moins la miséricorde chrétienne' (II, 219). Indeed, as we shall see, it is even possible for an individual to engage in 'une apparence de piété qui le trompe lui-même' (II, 216). It is owing to the risks inherent in attempting to distinguish between sincerity and hypocrisy that Bourdaloue, following $\mathrm{St}$ 
Augustin's recommendation not to judge prematurely, elects to focus in his sermon not on hypocrisy itself but instead on the pernicious effects of perceived hypocrisy on others. ${ }^{2}$ In an interesting reversal, it is in the context of the weak would-be believer who is put off for fear of being mistaken for a hypocrite that Bourdaloue dares to put forward not a series of defined acts but a series of semi-defined qualities that distinguish one from the other:

C'est une lumière [...] c'est un or pur qui se sépare sans peine de tous les autres métaux [...]. Une humilité sans affectation, une charité sans exception et sans réserve, un esprit de douceur pour autrui et de sévérité pour soi-même, un désintéressement réel et parfait, une égalité uniforme dans la pratique du bien, une soumission paisible dans la souffrance, tout cela est au-dessus des jugements mauvais (Sur l'hypocrisie, II, 240). ${ }^{3}$

But of course, these qualities, characterized primarily by their motivation, are less easy to discern than the acts (e.g. visiting the sick) that he has already observed are no guarantee of true sincerity.

Having established that the vrai--faux model is not a simple matter of a need to distinguish between the two owing to their outward similarities, let us return to Molière's famous quotation, ‘j'ai mis tout l'art, et tous les soins qu'il m'a été possible pour bien distinguer le personnage de l'Hypocrite d'avec celui du vrai Dévot'. If the hypocrite in question here is undoubtedly Tartuffe, ${ }^{4}$ his authentic counterpart has proven to be highly

\footnotetext{
${ }^{2}$ One of Bourdaloue's categories is very much like Orgon: the would-be sincere dupe, who is taken in by the hypocrite.

${ }^{3}$ Bourdaloue does, however, avoid the ambiguity noted in Perefixe's comments when he complains about the 'esprits profanes' who 'ont entrepris de censurer l'hypocrisie, $[\ldots]$ en concevant et faisant concevoir d'injustes soupçons de la vraie piété, par de malignes représentations de la fausse' (II, 236, my emphasis).

${ }^{4}$ The notion of the faux dévot is problematized in Prest 2010, but here the reference seems clear.
} 
elusive. ${ }^{5}$ As many critics have observed, it is possible to argue that both Orgon and Mme Pernelle are vrais dévots in the sense that they are sincere -- even if misguided -- in their faith. However, the seventeenth-century took a dim view of the self-righteous selfdeceiver, as this mother and son surely are. Bossuet, for instance, denounces as hypocrites those who convince themselves (wrongly) of their own sincerity (Bossuet 2001, 214), while, as we have seen, Bourdaloue condemns both those who are taken in by their own hypocrisy and those who are taken in by that of others. ${ }^{6}$ They fail on both counts, and the would-be believer is left doubting his/her own sincerity as well as that of all others.

Meanwhile, Cléante, who invites Orgon explicitly to distinguish 'Entre l'Hypocrisie, et la Dévotion' (Tartuffe, I. 5. 332), confidently asserts that he possesses this vital knowledge: 'je sais [...]| Du faux, avec le vrai, faire la différence' (353-4). Yet his famous bipartite speech that purports to portray first the faux and then the vrai dévot in fact offers a portrait of the faux dévot and then a portrait of the vrai dévot based largely on what he is not (i.e. a faux dévot):
CléANTE Ce ne sont point du tout Fanfarons de vertu,
On ne voit point en eux ce faste insupportable,
Et leur Dévotion est humaine, est traitable.
Ils ne censurent point toutes nos actions,
Ils trouvent trop d'orgueil dans ces corrections,
Et laissant la fierté des paroles aux autres,
C'est par leurs actions, qu'ils reprennent les nôtres.
L'apparence du mal a chez eux peu d'appui,

\footnotetext{
${ }^{5}$ Myrna Zwillenberg in her search for someone to oppose Tartuffe considers and dismisses in turn Marianne, Damis, Elmire, Dorine, Cléante and finally even Mme Pernelle. Interestingly, Valère is not even considered (Zwillenberg 1975, 586). ${ }^{6} \mathrm{He}$ asks rhetorically if having been taken in by hypocrisy is a good excuse before God and concludes that 'cette excuse sera l'une des plus frivoles dont un chrétien se puisse servir' (Sur l'hypocrisie, II, 242).
} 
Et leur âme est portée à juger bien d'autrui;

Point de cabale en eux, point d'intrigues à suivre;

On les voit, pour tous soins, se mêler de bien vivre.

Jamais contre un Pécheur ils n'ont d'acharnement.

Ils attachent leur haine au Péché seulement,

Et ne veulent point prendre, avec un zèle extrême,

Les intérêts du Ciel, plus qu'il ne veut lui-même. (I. 5. 388-402)

Unlike Bourdaloue, then, Cléante makes the reassuring claim that the distinction is easy to make. But his examples of evidence of true devotion are considerably less concrete than his counter-examples. While Cléante's faux dévot has many recognizable traits including his 'faste insupportable', his 'corrections', his 'intrigues', 'acharnement' and his 'zèle extreme', the vrai dévot is discreet almost to the point of being invisible. Indeed, it is his near invisibility that seems to be the vrai dévot's defining characteristic, which of course makes him very difficult to identify. ${ }^{7}$

If it is by his actions that we can know an individual (a concept with the potential to please both readers of the Bible and the more empirically minded among Molière's contemporaries), what exactly those actions are is never made clear. Gossman has observed that "what [Cléante] distinguishes among the actual manifestations of piety [...] is not the true and the false; it is the obviously false and the possibly true' (Gossman $1963,124){ }^{8}$ Yet, the doubt may extend even further, to both good and bad deeds, since Cléante's notion whereby 'c'est par leurs actions qu'ils reprennent les nôtres' is followed the dictum 'l'apparence du mal a chez eux peu d'appui' (my emphasis). If seemingly

\footnotetext{
${ }^{7}$ This problem is also acknowledged by Bourdaloue who asks, 'Pourquoi la vraie dévotion est-elle si peu connue, et pourquoi, au contraire, connaît-on si bien la fausse? C'est que la vraie dévotion se cache, parce qu'elle est humble; au lieu que la fausse aime à se montrer et à se distinguer. [...] plus elle se montre, plus on en découvre la fausseté' (Pensées de la vraie et de la fausse dévotion, IV, 372).

${ }^{8}$ Orgon famously learns this lesson far too well when, finally disabused of Tartuffe, he melodramatically claims that he will 'renonce[r] à tous les gens de bien' (V.I.1604).
} 
bad deeds are not necessarily taken as such, it is because appearances, both good and bad, are unreliable.

While Cléante struggles to come up with reliable evidence of true devotion, he does name a series of supposedly exemplary dévots: Ariston and Périandre, then Oronte, Alcidamas, Polydore and Clitandre (I. 5. 385-6). ${ }^{9}$ As Plantié concedes (Plantié 1972, 915), the names Ariston and Périandre, 'peuvent n'être que ceux de philosophes, de "sages" de l'ancienne Grèce, ou bien des noms à la mode dans les pastorales ou dans les romans' (Périandre is one of the seven sages of Greece, Ariston is a Greek philosopher cited by Montaigne). But Plantié then goes on to make a somewhat convincing case for a very different alternative interpretation whereby Ariston and Périandre designate, respectively François de Sales (who had been beatified in 1661 and was to be canonized in 1665) and Jean-Pierre Camus. ${ }^{10}$ Even if she is right (and she may well be), Jean Calvet is also correct when he writes that our examples 'ne sont pas présentés avec précision. Ce sont des ombres, qui portent des noms d'ombres' (Calvet 1980, 70). ${ }^{11}$ Whether generic or not, what is most significant about these examples is that they are not only discreet but actually absent from the stage and from the immediate world of Tartuffe. They cannot, therefore, act as a foil to our villain.

Who else is opposed to Tartuffe? If we approach the play in terms of its marriage plot, Valère is Tartuffe's rival for the hand of Marianne. It is to Valère that the final words of the play refer, stressing a way of life that prizes generosity and sincerity and which is certainly opposed to Tartuffe's model. ${ }^{12}$ But the most plausible candidate and

\footnotetext{
${ }^{9}$ Mme Pernelle also mentions one Orante in I.1.118 who, she claims, leads 'une vie exemplaire'.

${ }^{10}$ Plantié makes a strong case for why de Sales was in some ways more topical than, for instance, Pascal's Lettres provinciales (1656-57) (916).

${ }^{11}$ Hawcroft says simply that they are 'people they both know in the play-world' (2007, 102).

${ }^{12}$ On the subject of Valère, who is 'généreux et sincère', Suzanne Rossat-Mignod comments that, 'On voit aisément pourquoi cette morale purement humaine a choqué certains dévots intransigeants'(1966, 50).
} 
the name most frequently put forward and debated as the vrai dévot of the play is of course Cléante himself. Yet critical opinions of Cléante diverge wildly, particularly with regard to his religious standing, and the principal reason for this is surely that he cannot be made to fit the vrai--faux model that is usually applied. Michael Hawcroft has recently summarized the different prevailing views of Cléante and his defense of devotion (2007, 83-5). Hawcroft notes that Molière needed Cléante to be someone who would 'strike audiences as a sincerely and conventionally devout man of his times' and asserts that 'most [critics] think that he does constitute the adequate defender of the play that Molière says he sought to make him' (83). Hawcroft cites Calder for whom Cléante, 'illustrates, through both the soundness of his arguments and the modesty of his behaviour, how a good and honest man should behave' (83-4), ${ }^{13}$ and Lawrence, who notes 'how often the words of Cléante resemble those of Christ: distrust of ostentatious devotion, forbearance before the sins of others, toleration of sinners but not sin, opposition to Tartuffe's hypocrisy as Christ opposed the Pharisees' (83). He also mentions Scherer, who sees combined in Cléante, 'la sagesse humaine' and a 'dévot' who practises the Christian virtues of moderation, charity and forgiveness (84). Ferreyrolles, 'who also sees Cléante as the representative of true religion in the play' is mentioned in a footnote $(84 n 15)$. To this list, we might add, notably, Cairncross who writes emphatically, 'Il y a en effet un chrétien modèle, mais il est seul. C'est Cléante' (Cairncross 1972, 896).

But Hawcroft's line-up is in need of nuancing. In the case of Calder, for instance, a false analogy is drawn between qualities that most of us admire today and religious conviction. A 'good and honest man', to use Calder's coinage, is not necessarily a man of religion. Lawrence and Scherer cast Cléante's qualities in a more religious light, but here too they are drawing on the assumption that personal integrity is evidence of religious conviction. I am arguing that this is a false assumption now, and was already beginning to be so in 1660s France. It is true that we are enjoined to judge a tree by its fruit, but we have also seen that such fruit is unreliable. And even if good deeds were evidence of a true heart, the uncomfortable suggestion in the 1660s was that neither the tree nor its fruit need be read in Christian terms at all. Cairncross, whom Hawcroft does not cite at this

\footnotetext{
${ }^{13}$ See also Calder 1993, 175.
} 
juncture, goes on, revealingly, to qualify Cléante's supposedly exemplary form of Christianity with, 'Malheureusement, le christianisme qu'il professe approche dangeureusement du déisme' (896). This is no mere detail; it changes everything.

A more perceptive and accurate evaluation of Cléante's hypothetical status as a vrai dévot is given by Richard Parish, who points out:

Cléante does not in any respect constitute the positive correlative of which Tartuffe is the deformation; the 'true' Tartuffe would in all good faith be devoted to prayer, fasting, mortification of the flesh, chastity, almsgiving, and so forth. The counterpoint offered by Cléante represents an entirely false complementarity easily emptied of conviction; his recipe for dévotion [...] is spiritually insubstantial even in the context of the most urbane traditions of counter-reformation belief and practice. (Parish 1991, 86) ${ }^{14}$

If Cléante and Tartuffe are (dramatically) opposed, they are not (devotional) opposites. ${ }^{15}$ Some critics have tried to squeeze Cléante into the more flexible model of the Christian humanist, thereby retaining the vrai-faux dévot dichotomy and accounting for Cléante's undeniable humanist tendencies. The most committed and the most convincing proponent of this view is Plantié, who casts Cléante as a follower of François de Sales. While it is true that de Sales in his best-selling Introduction à la vie dévote (first published in 1608 and reissued several times in the course of the seventeenth century) attempted to reconcile being in the world with religious devotion, it is also the case that 'he still retains, in modified form, the Pauline antithesis of the world and God' and 'his concessions serve only to palliate what is a predominantly Christian rather than humanist

\footnotetext{
${ }^{14}$ Hawcroft, however, is unconvinced (2007, 84-85).

${ }^{15}$ Moore claims that Molière has Cléante express, 'the artistic opposite of Tartuffe's exaggerated and false piety' (Moore 1962, 7 my emphasis).
} 
attitude to life' (McBride 1977, 69). ${ }^{16}$ And, as Plantié herself admits, by the 1660s the tendency towards reconciling humanism and devotion was dwindling, and Christians were faced instead with a starker choice between, broadly, rigorism on the one hand and laxism on the other (918). ${ }^{17}$ This is the context in which the Tartuffe controversy may helpfully be read: it is not so much a question of sincerity as a question of world view, of the place of religion in the world and of the world in religion. This context may also shed light on one of the most famous lines of the play, 'ah! Pour être dévot, je n'en suis pas moins homme' (III. 3. 966), which may not, as is usually understood, be evidence of hypocrisy so much as a gently satirical reference to a form of religion or religious practice that was no longer acceptable.

Returning to Cléante, Père Le Moine's La dévotion aisée (first published in 1652 but reissued during the Tartuffe controversy in 1668), chimes with much of what he says, both in its commitment to moderation and proportion, and in its portrait of what devotion is not: 'on en a fait un Phantôme décharné, qui fait le Caresme toute l'année, qui met le vendredy-Saint à tous les jours' and declaring that 'les severitez excessives ne sont pas moins scandaleuses que les indulgences mal ménagées' (Le Moine 1688, 4 \& 5). Like Cléante, Le Moine perceives zealotry and austerity as evidence of false devotion, i.e. of a misguided form of devotion and not necessarily an insincere one. But where Le Moine is a throw-back to the Christian humanism of the first part of the century, Cléante seems to be looking in a different direction. And where Le Moine is trying to bring the 'Egarez' and the 'Apprehensifs' (epistre, np) back into the fold, Cléante seems to dispense with God and the Church altogether. The zealots in turn would of course consider Le Moine's position evidence of laxism and therefore of false (because inadequate) devotion. ${ }^{18}$

\footnotetext{
${ }^{16} \mathrm{McBride}$ comments that 'it is by implication rather than by intention that the thought of the play appears to me to relate more closely to the humanist libertin érudit of the century than to the Christian humanist' (70).

${ }^{17}$ Only the hypocrite, like Tartuffe, can display quasi Jansenist rigorism and the type of Jesuitical laxist casuistry mocked by Pascal in his Lettres provinciales.

${ }^{18}$ We remember that Bossuet, among others, preached about the necessity to choose between the world and God, between the mondain and the dévot. In his Carême du
} 
In order to appreciate Cléante's failure to oppose the faux dévot with his authentic, religious counterpart (even a hypocritical one), one may compare his inadequate portrait with that of a close contemporary who produced a satirical portrait of the faux dévot in opposition to the vrai in a poem entitled Les Pharisiens du temps ou le dévot hypocrite (Garaby 1888). The comparison with Garaby de la Luzerne is called for as Garaby himself would retrospectively call his own satirical creation, 'mon Tartuf, aisné de celuy de Molière de sept à huit ans' (Garaby 1888, 52). In stark contrast with Molière's play, Garaby's satire of the early 1660 s was expected to reach only a limited audience in Normandy and above all to be read in private. But it is all the more telling that in a piece as daring and provocative in its portrayal of religious zealotry-cum-hypocrisy as this (at one point he rhymes 'dévotisme' with 'puta[i]nisme', 62), Garaby nonetheless allows space--albeit only a few lines--for the real thing:

Je n'entends pas dévot de ces gens sans cabale, Qui, sur la preud'hommie appuyant leur morale, Suivent tout simplement les loix que Jésus-Chrît, Dans son saint Evangile à ses enfans prescrit.

Ce monde là n'est bon, en ce temps de finesse, Qu'à fournir d'auditeurs le Prône de la Messe. (Garaby 1881, 52)

It is significant that Garaby (as Cléante will do) mentions the word 'cabale' -- a clear reference to the work of the Compagnie du Saint Sacrement, whose anti-Jansenist scandal mongering in Garaby's home town of Caen was the direct inspiration for his piece, and whose shadowy interference in Parisian and court life was perceived as threatening by Mazarin and later by the young Louis XIV. But it is significant that Garaby's world has

Louvre, for instance, we read the injunction 'ne menez pas une vie moitié sainte et moitié profane; moitié chrétienne et moitié mondaine' (Bossuet 2001, 229). And, as Calvet points out, the opening scène of Tartuffe opposes le dévot and le mondain (140) and not, we note, faux dévots and vrais dévots. 
something that Cléante's does not appear to have: the authentic, Christ-like believer whose example will encourage those around him to go to church.

Where Garaby's attack on false devotion is considerably more biting than Molière's, the fact that he does not appear to push any mondain and therefore antireligious agenda in the poem renders it ultimately less explosive in content (as well as in form) than Molière's seemingly more anodyne play. This in turn may nuance our understanding of the significance and impact of some of the changes we think Molière made to the original play as well as his apparent deference to the question of the place of matters religious on stage. In his preface, Molière writes about how he has, 'retranché les termes consacrés, dont on aurait eu peine à lui [Tartuffe] entendre faire un mauvais usage'. But might not this in fact be precisely part of the problem? In attempting to render the play less offensive, Molière may in fact have made it more profoundly threatening (if less obviously so), by leaving out the vrais dévots, véritable dévotion, and, worse still, God himself. ${ }^{19}$ While it is, of course, inappropriate for God to feature in a comedy, his absence also does him a disservice, particularly in a comedy as topical as this and one that is, by the standards of the day, quite so lifelike. Molière's onstage world is recognizably a comic version of that known to his theatre audience; if God is absent from one, might not the suggestion be that he is absent from the other as well?

Similarly, one of Molière's most important gestures towards rendering the second version of the play acceptable was to make Tartuffe 'un homme du monde', an impostor and not a hypocrite. While this choice softened the issue of religious hypocrisy among ecclesiastics (or semi-ecclesiastics), it also helped remove God from the equation, by situating the play in a more secular universe. As Couton has shown, many seventeenthcentury writers maintained that religious hypocrisy, while a sin (mortal or venal, depending on the instance) could still be of some marginal benefit, depending on the motive and the consequences (Couton 1969). And we have already seen that faux dévots are capable of good works, for that is an essential part of their disguise. Couton reminds

${ }^{19}$ As Plantié notes, 'Dieu' is used only eleven times and nearly always in expressions and formulae that are without religious signification' (926). 'Le ciel' on the other hand, with its more neutral and secular connotations is used quite frequently. 
us too that, in the Dictionnaire de Théologie catholique we are told that, 'Le respect, même simplement extérieur, des lois de Dieu et de l'Eglise est déjà un certain hommage rendu à la sainteté de ses préceptes par les lâches qui n'ont pas le courage de les observer' (Couton 1969, 413). If Tartuffe is religious, then religion at least still exists. As Tartuffe (both the person and the play) became more secular, they may both have become more insidiously threatening.

Having noted the striking absence of vrais dévots from Molière's play, it should nevertheless be noted that Molière acknowledges their existence beyond the play world when he writes in his preface:

C'est aux vrais dévots que je veux partout me justifier sur la conduite de ma comédie; et je les conjure [...] de ne point condamner les choses avant que de les voir, de se défaire de toute prévention, et de ne point servir la passion de ceux dont les grimaces les déshonorent. (Molière 2010, 92)

Molière appears to be seeking approval for his play not only from Louis XIV (whose approval he appears always to have had) but also from influential vrais dévots, claiming that an appreciation of theatre is not incompatible with true devotion. And he may genuinely have failed to see an incompatibility that had only relatively recently been sharpened in the tense climate of the counter-reformation of the post-Fronde era. Although anti-theatrical Christian sentiment dates back at least as far as the Church Fathers, it is also the case that pious individuals such as Bossuet, who had deigned to visit the theatre earlier in the century now felt obliged to condemn it. For as well as being the decade of the Tartuffe controversy, the 1660s was a decade of renewed anti-theatrical sentiment as evidenced by, among others, Conti's Traité de la comédie et des spectacles, selon la tradition de l'église (Paris: Louis Billaine, 1667). There is no doubt, then, that the theatre had become a touchstone for the broader debate regarding the reconcilability or not of a worldly existence and a religious one. Indeed, Nicole says as much in the opening sentence of his Traité de la comédie: 
Une des grandes marques de la corruption de ce siècle est le soin que l'on a pris de justifier la Comédie, et de la faire passer pour un divertissement qui se pouvait allier avec la dévotion. Les autres siècles étaient plus simples dans le bien et dans le mal [...]. Mais le caractère de ce siècle est de prétendre allier ensemble la piété et l'esprit du monde. (Thirouin 1997, 32)

Meanwhile, in a stroke of provocative genius, Molière in his preface places the vrais dévots who are at least potentially supportive of his play in opposition to those who oppose it. But to cast his opponents (most of whom appear to have been zealots rather than hypocrites) as Tartuffes, while rhetorically ingenious, clouds the issue, for, to the extent that we can ever know, the play divided the dévots not into sincere believers and hypocrites but along other lines. The anti-Tartuffe faction was composed largely of antiworldly zealots (many of whom must have been sincere in their beliefs), while the proTartuffe factions included those who genuinely saw no incompatibility between the theatre and their religious integrity and those who chose to overlook any such incompatibility (as well as those who were not religiously inclined at all). There were thus hypocrites and non-hypocrites on both sides of the divide. Here again, it is clear that sincerity is not the principal issue at stake in this controversy.

But neither is it only a question of the position of worldly matters within a religious climate. While Molière's placets and preface allow for the existence of true devotion (even if he comes dangerously close to equating this with approval of his play), we have seen that examples of it are sorely lacking in the play. In what moral universe does this work take place? Returning to Molière's preface, we notice that, when alluding more specifically to Tartuffe's on-stage foil, Molière writes, significantly, not of a vrai dévot, but of a véritable homme de bien. As with Molière's vrai dévot, it is not absolutely clear to whom he is referring but the words 'que je lui oppose' in the second instance strongly suggest that (in contrast with what I have argued regarding the vrai dévot), the véritable homme de bien does appear in the play. And the person in question is surely Cléante. If this is the case, the religiously ambiguous morality of which he is the champion is both condoned by the playwright and singled out, albeit discreetly, as being extra ecclesiam. Yet, the majority of critics have assumed that there exists if not a 
complete overlap then a close correspondence between the categories of vrai dévot and véritable homme de bien in Molière's discourse. But I would like to suggest that the designation véritable homme de bien denotes for Molière here a third category that sometimes sits outside the dévot paradigm, vrai or faux. I also argue that it is in this slippage between vrai dévot and véritable homme de bien that we find a value-judgment and, more insidiously, the suggestion of an alternative worldview that was perhaps more threatening to the religious establishment than Molière's portrayal of religious hypocrisy (or its own internal divisions).

The most obvious difference between a vrai dévot and a véritable homme de bien is that the former is, by definition, linked with organized religion, while the latter need not be. Molière is thus subtly suggesting not only that there exists a social group, significant enough to merit its own linguistic signifier, that can be found outside the Church (extra ecclesiam) ${ }^{20}$ but also that such people are or can be morally superior to the more widely recognized group that operates uniquely within it (intra ecclesiam). In other words, he suggests both that piety does not necessarily equate with genuine goodness and that genuine goodness need not be aligned with religion. This shifts the focus away from bad or immoral religion (the faux dévot à la Tartuffe) and onto good or moral secularism (the véritable homme de bien à la Cléante). Here too we can draw upon additional nontheatrical seventeenth-century texts to shed light on the degree to which this is radical or provocative. The famous notion of the seventeenth-century honnête homme is predominantly Christian in nature, if only sometimes by default. The Abbé de Gérard's Caractère de l'honneste-homme morale (1682), for instance, aims to demonstrate, 'la bonne intelligence de la Foi \& de la Raison, de la probité \& du Christianisme quand on les prend par le bon endroit' (Gérard 1682, np). But the very fact that Gérard was moved to write this also indicates that the matter was up for debate. If we compare Garaby's Christ-like church goer with Cléante (or even Valère, who, let us remember, is criticized by Orgon for being an invisible church-goer II. 2. 525) we can see that, while they are

${ }^{20}$ This calls to mind the dictum 'Extra ecclesiam nulla salus' -- outside the church there is no salvation. While Molière does not of course engage with the question of salvation, he does suggest that there can be goodness and morality outside the church. 
both broadly moral, and while their different forms of morality appear to have much in common, they stem from quite different models of existence.

The anonymous author of the Lettre sur la comédie de l'Imposteur (20 August 1667) describes Cléante both as 'un véritable honnête homme' and as someone who promotes an 'excellente morale' (Molière 2010). Whereas I am claiming that there is a significant difference between a vrai dévot and a véritable homme de bien in Molière's preface, there appears to be an almost complete overlap between Molière's véritable homme de bien and the véritable honnête homme of the Lettre. Both are véritables and both are described in positive secular terms (even the word homme is telling in this regard). Returning to the question of how a véritable homme de bien or honnête homme might compare with a vrai dévot, the anonymous author of the Lettre comments that Cléante's words in I. 5 are, 'des réflexions très solides sur les différences qui se rencontrent entre la véritable et la fausse vertu' (1174; my emphasis) and comments on how 'le Frère de la Bru commence déjà à faire voir quelle est la véritable dévotion, par rapport à celle de M. Panulphe' (1171). Here again, I think that a subtle but important distinction is being made, signalled by the word véritable. The suggestion is that the oxymoronic véritable dévotion being put forward in opposition to that of Tartuffe, as it is described in the Lettre, is not simply, to borrow Parish's phrase, the positive correlative of which Tartuffe is the deformation, but something rather different. If Cléante's model is extra ecclesiam and if it is judged by Molière and by the author of the Lettre to be véritable, it is in contrast not only to Tartuffe's hypocritical form of religious devotion but also to any truly authentic examples of religious devotion (of which, as we have seen, there appear to be none in the play). Crucially, then, it is not only in comparison with the faux dévot that the vrai dévot suffers, but also with the veritable homme de bien.

My reading of the slippage between a vrai dévot and a véritable homme de bien in the Tartuffe controversy is supported by an examination of definitions of the terms in seventeenth-century dictionaries. In both Furetière (1690) and the Académie Française (1694), the terms dévot and dévotion are, as one would expect, defined within a religious context. Significantly, in both dictionaries, the word véritable is given a wholly secular context. In Furetière, the first example after the definition of 'véritable' as 'qui est vray, qui dit verité', is 'Un véritable homme d'honneur tient sa parole', while in the Académie 
Française dictionary, we find 'Un homme est véritable dans ses paroles'. Furetière’s 'véritable homme d'honneur' is thus closely aligned with Molière's 'véritable homme de bien' and with the Lettre's 'véritable honnête homme'. And none of them has anything to do with going to church or even, it would seem, with God. But all are associated with truth-telling. We find similar nuances in Richelet's 1680 dictionary, (although he includes among his definitions of dévotion a secular form of personal devotion towards another individual, but only after devotion to God and the saints). These are of course the same dictionaries in which the word dévot is tainted by the notion of the faux dévot, with Tartuffe as its primary example. In that sense Molière's enemies were right to fear the corruption of the vrai by the faux..$^{21}$ But what is most threatening of all is the underlying, if subtle, sense that there is a closer alignment in the dictionaries between secularism and truth than between devotion and truth; and a closer alignment in Molière's preface and in the Lettre between secularism and morality than between religion and morality. This being the case, it is no wonder that Tartuffe was (and continued to be) felt to be so threatening in certain religious circles. ${ }^{22}$

Molière uses the term véritable on two other occasions during the Tartuffe controversy. The first (which comes chronologically before the example we have just examined) is in the second placet to the king of 1667 . Here the playwright laments the fact that, 'les Gens que je peins dans ma Comédie' have succeeded in taking in, 'de véritables Gens de bien, qui sont d'autant plus prompts à se laisser tromper qu'ils jugent d'autrui par eux-mêmes' (194). This seems to be a reference to Lamoignon, president of the Parisian Parlement, who had, in the king's absence, just put the ban back in place

${ }^{21}$ Bourdaloue notes that 'Jusque-là que ce qui devrait être un éloge est devenu, par la triste décadence, un reproche; et que le terme d'homme dévot, de femme dévote, qui dans sa propre signification exprime ce qu'il y a dans le christianisme de plus respectable, porte présentement avec soi comme une tache qui en obscurcit tout l'éclat et le ternit' (Sur la vraie et la fausse piété, II, 216-17).

22 Even after the ban had been lifted in France in 1669, there were further attempts to prevent performances of Tartuffe from taking place in other places, including Québec and Rome. 
after a single performance of the revamped L'Imposteur. We know that Molière had met with Lamoignon to discuss the matter and, given the openly combative tone of the rest of the placet, it is plausible to think that Molière is sincere in describing him as a véritable homme de bien. Lamoignon's is a particularly interesting case, for he had been a keen member of the Compagnie du Saint Sacrement (the dévot society par excellence) but had had to side with Mazarin and the young Louis XIV in 1660 when all such secret societies were banned. Although he was surely conflicted about the matter, Lamoignon was above all faithful to the requirements of his professional occupation while at the same time seems to have managed to keep the name of the Compagnie du Saint Sacrement out of the official documents condemning it. He was, then, a dévot; sincere as far as we know, zealous yet reasonable where some of his colleagues were not. With this information in mind, the distinction that Molière appears to be drawing in this instance is between the uncompromising zealots of the now banned Compagnie du Saint Sacrement (who we know from their own records orchestrated the anti-Tartuffe campaign) and the more measured attitude of Lamoignon who is, nonetheless, still closely linked to these (mainly sincere) zealots whom Molière insists on likening to Tartuffe. Here, too, then the véritable-ness is about moral integrity and a lack of misplaced zealotry rather than sincerity of belief. ${ }^{23}$

The other example, this time in the preface, appears also to refer to Lamoignon and his ilk. Here Molière laments the fact that 'les hypocrites' have managed to 'jeter dans leur parti de véritables Gens de bien, dont ils préviennent la bonne foi, et qui par la chaleur qu'ils ont pour les intérêts du Ciel, sont faciles à recevoir les impressions qu'on veut leur donner' (92). These individuals are taken in owing to their religious convictions and it is their very integrity that makes them naïve and vulnerable to the influence of

${ }^{23}$ Incidentally, he may also be distinguishing between Lamoignon who was, we think, no hypocrite in the received sense (and who was praised in Boileau's epistles), and Perefixe who was satirized for his numerous affairs with women and who allegedly died in the arms of one such (Coquelin c.1884, 27 \& 28). Meanwhile, Brossette observed that, 'Toute la mauvaise humeur de Molière retomba sur Mgr l'archevêque qu'il regardoit comme le chef de la cabale des dévots, qui lui était contraire' (Lacour 1999, 53n). 
Molière's hypocrites. So in the case of Lamoignon, the véritables gens de bien are opposed to the anti-Tartuffian dévots who are labelled faux dévots or hypocrites or Tartuffes not because they are necessarily insincere, but because their zealotry is perceived as being misplaced.

Returning to the questions and assumptions with which we began, my contention is that there are no vrais dévots in the play and that the slippage between a vrai dévot and a véritable homme de bien in Molière's preface and elsewhere hints at a worldview that discreetly challenges religion's monopoly on morality at a time when the church was striving to tighten her grip on it. In Garaby de la Luzerne's satire, the vrais dévots still have their place, in church. But while Molière's véritables gens de bien can be dévots, they are liable to be duped by ill-advised zealots. I would like to suggest that the fact that the véritable homme de bien with the most integrity remains the fictional Cléante (who calls for moderation, for a form of devotion that is humaine and traitable) is more discreetly but ultimately more profoundly threatening than Orgon's blindness or Tartuffe's imposture. The scandal of Tartuffe is not simply that the church might include religious hypocrites or even that their portrayal would inevitably tarnish the reputation of sincere Christians; rather, it is, above all, that genuine goodness might be beginning to escape the confines of the church. Molière was no revolutionary, but the controversy over his Tartuffe did highlight some of the cracks in the structure of the Ancien Régime more than a century before the principles of the veritable homme de bien officially replaced those of the vrai dévot.

Acknowledgments:

Research for this article was undertaken with the generous assistance of the Carnegie Trust for the Universities of Scotland.

\section{References:}

Bossuet, J.-B. (2001). Sermons: Le Carême du Louvre 1662. C. Cagnat-Debœuf (Ed.). Paris: Gallimard.

Bourdaloue, L. (1864). CEuvres complètes de Bourdaloue. Prêtres de l'immaculéeconception de Saint-Dizier (Eds). 4 vols. Bar-le-Duc/Paris: Guérin. 
Cairncross, J. (1972). Tartuffe, ou Molière hypocrite. Revue de l'Histoire Littéraire de la France, 72, 890-901.

Calder, A. (1993). Molière: The Theory and Practice of Comedy. London: Athlone Press. Calvet, J. (1950; 1980). Essai sur la séparation de la religion et de la vie: Molière dans le drame spirituel de son temps. Lanore/ Paris: Nizet.

Coquelin, C. (c1884). Tartuffe (bound holograph). Maria H. Dehon Polk Collection of Constant Coquelin, Beinecke Rare Book and Manuscript Library GEN MSS 453 (Box 2, folder 25).

Couton, G. (1969). Réflexions sur Tartuffe et le péché d'hypocrisie, cas reserve. Revue d'Histoire littéraire de la France, 69, 404-13.

Le Dictionnaire de L'Académie française dedié au Roy (1694). Paris: Veuve Coignard. Le dictionnaire universel d'Antoine Furetière (1690). 2 vols. La Haye and Rotterdam: A \& R Leers.

Garaby de la Luzerne: Satires inédites (1888). E. de Beaurepaire (Ed.). Rouen:

Espérance Cagniard.

Gérard, A. de (1682). Le caractère de l'honneste-homme morale. Paris: Huré.

Gossman, L. (1963). Men and Masks: A Study of Molière. Baltimore: Johns Hopkins University Press.

Hawcroft, M. (2007). Molière: Reasoning with Fools. Oxford: Oxford University Press.

Le Moine, P. (1652; 1668). La dévotion aisée. Paris: Sommaville/Cottin.

Lacour, L. (1877; 1999). Le Tartuffe par ordre de Louis XIV. Paris/Nîmes:

Claudin/Lacour.

Laverdet, A. (Ed.) (1858). Correspondance entre Boileau Despréaux et Brossette. Paris:

Techener.

Lettre sur la comédie de l'Imposteur (1667). In Molière, Euvres complètes (2010) pp. 1170-99.

McBride, R. (1977). The Sceptical Vision of Molière: a Study in Paradox. London: Macmillan.

Molière (2010). Euvres complètes. Forestier, G. et al (Eds) 2 vols. Paris: Gallimard. Moore, W. G. (1949; 1962). Molière: A New Criticism. Oxford: Clarendon Press. 
Nicole, P. Traité de la comédie. In Thirouin, L. (1997). L'aveuglement salutaire: Le réquisitoire contre le théâtre dans la France classique. Paris: Champion.

Parish, R. (1991). Tartuf(f)e ou l'imposture. Seventeenth Century, 6 (1), 73-88.

Perefixe, H. (1667). Ordonnance de Monseigneur L'Archevêque de Paris'. In Molière (2010), II, 1168-69.

Les Plaisirs de l'Île Enchantée, Troisième Journée (1664). In Molière (2010), I, 589-99.

Plantié, J. (1972). Molière et François de Sales. Revue d'histoire littéraire de la France, 72, 902-927.

Prest, J. (2010). Troublesome Sensual Appetites or Who is the Real Faux Dévot? In R.

Lalande and B. Landry (Eds), Nourritures: Actes du 40e congrès annuel de la North American Society for Seventeenth-Century French Literature. Biblio 17, Tübingen:

Gunter Narr. (pp. 253-63).

Richelet, P. (1680). Dictionnaire françois contenant les mots et les choses. 2 vols.

Geneva: Jean Herman Widerhold.

Scherer, J. (1966; 1974). Structures de Tartuffe. Paris: SEDES.

Rossat-Mignod, S. (1966). La portée de Tartuffe à la fin du XVIIe siècle. Europe, 441-42, 44-51.

Thirouin, L. (1997). L'aveuglement salutaire: Le réquisitoire contre le théâtre dans la France classique. Paris: Champion.

Zwillenberg, M. K. (1975). Dramatic Justice in Tartuffe. Modern Language Notes 90 (4), 583-90. 